\title{
Snak, Claas and Bastiaan's Struggle for Freedom
}

\author{
Three Curaçaoan Enslaved Men and Their Court Cases About \\ the Free Soil Principle in the Dutch Republic
}

TIM VAN POLANEN

In the Dutch Republic slavery was not permitted on its soil in Western Europe. Enslaved people obtained their freedom by setting foot on Dutch soil. In 1776 , the scope of this free soil principle was limited by a statute of the States General. From this moment onwards only slaves who remained in the Republic for longer than six months would automatically become free. In the literature, it was hitherto assumed that with the establishment of this statute the first debates about the scope of the free soil principle were initiated. This article demonstrates that this assumption is false. Previously, two court cases from 1735 and 1736, between two enslaved men from Curaçao and their masters, had already given rise to discussion. During these court cases, lawyers and judges elaborately debated the boundaries of the free soil principle. Did every enslaved person automatically obtain their freedom, or was, for instance, the permission of the master required to travel to the Dutch Republic? The two court cases give insight into what contemporaries thought about the free soil principle, thus shedding new light on the States General's statute of 1776.

In de Nederlandse Republiek bestond het principe dat slavernij op het eigen grondgebied in West-Europa niet was toegestaan. Tot slaaf gemaakte personen werden vrij wanneer zij voet op Nederlandse grond zetten. Dit principe van de vrije grond werd in 1776 beperkt door een plakkaat van de Staten-Generaal. Vanaf dat moment werden alleen nog slaven die langer dan zes maanden in de Republiek verbleven, meteen vrijgemaakt. Tot dusver werd in de literatuur aangenomen dat de totstandkoming van dit plakkaat voor het eerst een discussie teweegbracht over 
de reikwijdte van het principe van de vrije grond. Dit artikel laat zien dat deze aanname niet klopt, omdat reeds in 1735-1736 twee rechtszaken tussen Curaçaose tot slaaf gemaakten en hun meesters aanleiding gaven tot discussie. Advocaten en rechters debatteerden uitgebreid met elkaar over de grenzen van het principe van de vrije grond. Werd iedere tot slaaf gemaakte automatisch vrij of was bijvoorbeeld toestemming van de meester vereist om af te reizen naar de Republiek? De twee rechtszaken laten zien hoe tijdgenoten over het principe van de vrije grond dachten, en plaatsen daardoor het plakkaat van de Staten-Generaal uit 1776 in een nieuw perspectief.

\section{The free soil principle}

On 16 June 1714 the governor of Curaçao, Jeremias van Collen, wrote a letter to the Heren Tien in Amsterdam with a special request. Van Collen asked the board of the Dutch West India Company to temporarily imprison slaves who had fled from Curaçao to Amsterdam. Then, it would be possible to send them back to their masters in Curaçao. Other than what one would expect, Van Collen's request was denied. The Heren Tien answered that it was beyond their authority to detain slaves who had entered Dutch soil: 'coming to these lands, they immediately become free persons', they wrote. ${ }^{2}$

The Heren Tien's decision stems from the fact that slavery was not permitted on the Dutch Republic's soil in Europe. Already in the seventeenth century Hugo Grotius wrote in his Inleidinge tot de Hollandsche Rechtsgeleerdheid (1631) that for centuries 'in these lands all people have been regarded as free men'. ${ }^{3}$ Simon Groenewegen van der Made expressed a similar view. In 1649 he wrote that 'slavery has gradually receded through custom and nowadays its term has become obsolete with us'. ${ }^{4}$ Slavery did not occur on Dutch soil in Europe, where the keeping of slaves was not permitted. Confronted with this legal reality, the Heren Tien decided that there was only one possible solution. The government of Curaçao had to prevent slaves from stowing away in ships which sailed to the Dutch Republic. Measures against this had been taken. ${ }^{5}$ The States General decided, for instance, in a resolution

The author thanks Egbert Koops for his valuable comments and suggestions.

2 Resolution 3 October 1714 Heren Tien Amsterdam: Nationaal Archief Den Haag (hereafter NL-HaNA), WIC, 1.05.01.02, inv. nr. 4, 42v-43r.: 'dezelve in dese landen komende aenstonds vrije persoonen werden'.

3 Hugo Grotius, Inleidinge tot de Hollandsche Rechtsgeleerdheid (1631), eds. Folke Dovring, Herman Frederik Wilhelm David Fischer and Eduard Maurits Meijers (Leiden 1965) I.4.2.:
'[...] werden nu alle menschen in deze landen gehouden als vrijen'.

4 Simon van Groenewegen van der Made, Tractatus de legibus abrogatis et inusitatis in Hollandia vicinisque regionibus. Pars 1 (Amsterdam, ed. 1669) ad Inst. $1.8 \mathrm{nr}$. 3: 'Servitus paulatim ab usu recessit, eiusque nomen hodie apud nos exolevit'.

5 See: Han Jordaan, Slavernij en vrijheid op Curaçao: De dynamiek van een achttiende-eeuws Atlantisch handelsknooppunt (Zutphen 2013) 97-98. 
of 4 May 1731 'to order warships not to admit slaves on board that are running away from their masters' in order to 'prevent all difficulties as much as possible'. ${ }^{6}$

The free soil principle led to a conflicting situation. Contrary to the colonies in the West and East, slavery was not recognised on the Dutch Republic's soil in Europe. This contradiction was not peculiar to the Dutch. ${ }^{7}$ Since the High Middle Ages slavery had fallen into disuse throughout most of Western Europe, with the exception of the Iberian Peninsula. Over the course of the eighteenth century the free soil principle increasingly led to court cases in which slaves took legal action against their masters, arguing that they were free because they had touched the 'free' soil. Particularly in France, England, and Scotland there are notable examples of these freedom cases. In 1738 the Admiralty Court in Paris granted an enslaved man, Jean Boucaux, his freedom, because his master, Bernard Verdelin, had employed him as a cook in his residence in Paris (Boucaux v. Verdelin). ${ }^{8}$ The Court even ruled that Verdelin had to retroactively pay Boucaux's salary. Thereupon legislation was enacted that tried to limit the free soil principle. ${ }^{9}$ Nevertheless, 154 French slaves obtained their freedom between 1730-1790. Irrespective of the new law, the Admiralty Court in Paris and the Parliament of Paris continued to uphold the free soil principle. ${ }^{10}$

In England developments regarding the free soil principle culminated in the renowned freedom case Somerset v. Stewart (1772). ${ }^{11}$ Herein Lord Mansfield denied Charles Stewart the right to transport his slave James Somerset against his will to Jamaica. Although legally Somerset did not obtain his freedom, the significance of his case was immense. A turning-point was reached. For the first time it was unequivocal that on English soil enslaved people were entitled to resist their master's orders. Six years later Scotland went even further. ${ }^{12}$ In Knight $v$. Wedderburn the highest Scottish court, the

Resolution States General 4 May 1731,

'Oorlogscheepen geen slaaven in te neemen die van haare Meesters weggeloopen zyn', Grootplakkaatboek van de Staten-Generaal (hereafter Groot-plakkaatboek) VI (1746) 259: 'scheepen van oorlog ordre te geeven, van geen slaaven die haare meesters koomen te ontvlugten, aan haar boord te admiteeren [...] alle moejelijkheeden soo veel moogelijk voor te koomen'.

7 In 2011 the journal Slavery \& Abolition dedicated a special issue to the free soil principle in Europe: Slavery \& Abolition 32:3 (2011).

8 Sue Peabody, 'There Are No Slaves in France': The Political Culture of Race and Slavery in the Ancien Régime (New York
1997) 23-40. DOI: https://doi.org/10.1093/ acprof:oso/9780195101980.001.0001.

9 Peabody, 'There Are No Slaves in France', 41-56.

10 Peabody, 'There Are No Slaves in France', 55.

11 Somerset v. Stewart [1772] Lofft 1; [1772] 98 E.R. 499; [1772] 5 WLUK 5 .

12 John W. Cairns, 'Knight v. Wedderburn', in: David Dabydeen, John Gilmore and Cecily Jones (eds.), The Oxford Companion to Black British History (Oxford 2007) 244-246. DOI: https:// doi.org/10.1093/acref/9780192804396.001.0001; John W. Cairns, 'After Somerset: The Scottish experience', The Journal of Legal History 33:3 (2012) 291-312. DOI: https://doi.org/10.1080/01440365.201 2.730248 . 
Court of Session, decided that all slaves were free once they entered Scotland. The free soil principle applied to all.

For the Dutch Republic Bram Hoonhout, Karwan Fatah-Black, Han Jordaan, and Dienke Hondius have most recently written about the free soil principle. ${ }^{13}$ While Hondius gives more of a bird's-eye view of the free soil principle in the Netherlands from the sixteenth to the nineteenth century, the other authors predominantly focus on developments in the 1770s. These begin with two petitions to the States General in which several enslaved people, who had already visited the Dutch Republic, officially requested their freedom papers. ${ }^{14}$ In both instances the States General replied that these formalities were not necessary. By setting foot on Dutch soil, the petitioners had become free automatically. The Society of Suriname demanded clarification. ${ }^{15}$ How should these two resolutions be interpreted? Were they only granted for these two specific cases or did they represent a general rule that also applied to enslaved people in similar situations? The States General appointed a commission tasked with providing clarification. This resulted in the enactment of a statute on 23 May 1776 about 'the freedom of negro and other slaves that are brought or sent from the colonies of the nation to these lands.${ }^{16}$ In here, the scope of the free soil principle was limited considerably. Only slaves that stayed with their master on Dutch soil for more than six months automatically became free. Pursuant to article 5 a master even had the possibility to extend the term of six months. In the statute, the interests of Surinamese plantation owners evidently prevailed. For slaves it became more difficult, if not impossible, to invoke the free soil principle to their advantage.

The drafting process of the statute has led to the general assumption among historians that the scope of the free soil principle was determined onbereikbaar voor slaven', in: Marjolein 't Hart et al. (eds.), Wereldgeschiedenis van Nederland (Amsterdam 2018) 323-328; Karwan Fatah-Black, 'Terugkomen is niet hetzelfde als blijven. De handhaving van de ondergeschikte status van Surinaamse slaven na een reis naar Nederland', in: Anita van Dissel, Maurits Ebben and Karwan Fatah-Black (eds.), Reizen door het maritieme verleden van Nederland (Zutphen 2015) 177-187; Jordaan, Slavernij en vrijheid op Curaçao, 107-115; Dienke Hondius, 'Access to the Netherlands of Enslaved and Free Black Africans: Exploring Legal and Social Historical Practices, SixteenthNineteenth Centuries', Slavery \& Abolition 32:3 (2011) 377-395. DOI: https://doi.org/10.1080/
0144039X.2011.588476. One of the first Dutch scholars writing about the free soil principle was: Emy Maduro, 'Nos a bai Ulanda - Antilianen in Nederland 1634-1954', in: Gert Oostindie and Emy Maduro (eds.), In het land van de overheerser II: Antillianen en Surinamers in Nederland, 1634/1667-1954 (Dordrecht 1986) 133-228.

14 The petitions are from 1771 and 1773: NL-HaNA, Sociëteit van Suriname, 1.05.03, inv. nr. 65, 178-180.

15 NL-HaNA, Sociëteit van Suriname, 1.05.03, inv. nr. $65,180-188$.

16 Statute States General 23 May 1776, 'De Vryheid der Neger- en andere Slaaven, welke uit de Colonien van den Staat naar dese Landen overgebragt of overgesonden worden', Grootplakkaatboek IX (1796) 526. 
during this period. ${ }^{17}$ The two resolutions of the States General seem to trigger a new debate about the question under which circumstances a slave could successfully invoke the free soil principle. This article shows, however, that this assumption is false. The question about the scope of the free soil principle was answered earlier. It was not in the 1770 , but in the 1730 s that the free soil principle was shaped for the first time. Two court cases from 1735-1736 have been of pivotal importance and are at the centre of this article. The main actors are three Curaçaoan enslaved men, Snak, Claas and Bastiaan who fled to Amsterdam on 3 May 1735 on board of the ship the Maria Jacoba of captain Steven van Lint. Once they arrived in Amsterdam, their masters, Jan van Schagen and Paulina Heijer, took the matter to court. Just as in the French, English and Scottish cases, the masters demanded that their slaves were sent back to them as their legal property, while the enslaved people invoked the free soil principle. Lawyers in court and judges in chambers debated about the free soil principle. What were the boundaries? Did every slave who touched Dutch soil obtain their freedom without any further distinction or was, for instance, their master's permission required to travel to the Dutch Republic? The court cases, of which one even reached the High Court of Holland, Zeeland and West-Friesland (Hoge Rad van Holland, Zeeland en West-Friesland), provide a clear answer. Accordingly, fifty years before the statute of the States General was enacted, the scope of the free soil principle had already been laid down.

Through various archival sources the court cases can be reconstructed in great detail. ${ }^{18}$ The legal diaries of two judges of the High Court, court records, and other archival pieces reveal a colourful image. One source deserves special attention: the alderman's journal (schepenjournaal) of the Amsterdam regent Egbert de Vrij Temminck (170o-1785). De Vrij Temminck sat as an alderman (schepen) in the Amsterdam Aldermen's Court (Schepenbank) multiple times. He made notes of parties' submissions during court sessions. ${ }^{19}$

\footnotetext{
b
} y, i.e. no more than one paragraph. They al use one of the available sources, the legal diary of Cornelis van Bynkershoek. See for instance: Maduro, 'Nos a bai Ulanda', 155; Alan Watson, Slave Law in the Americas (Athene 1989) 104-105; Bastiaan D. van der Velden, Ik lach met Grotius, en alle die prullen van boeken. Een rechtsgeschiedenis van Curaçao (Amsterdam 2011) 183; Hondius, 'Access to the Netherlands', 385; Karwan FatahBlack, Eigendomsstrijd. De geschiedenis van slavernij en emancipatie in Suriname (Amsterdam 2018) 125. bound book and a big pile of folios: NL-HaNA, Slingelandt de Vrij Temminck, 3.20.52, inv. nr. 423; NL-HanA, Slingelandt de Vrij Temminck, 3.20.52, inv. nr. 424. I found De Vrij Temminck's notes thanks to an unpublished PhD-thesis of Cees Kwanten from 1985 about Hermanus Noordkerk, the lawyer of one of the fugitive slaves. In his thesis, Kwanten wrote a separate chapter about Snak, Claas and Bastiaan. I had already come across many of the sources Kwanten mentioned. With De Vrij Temminck, however, he added an important piece of the puzzle. A typoscript of Kwanten's thesis is available in the library 


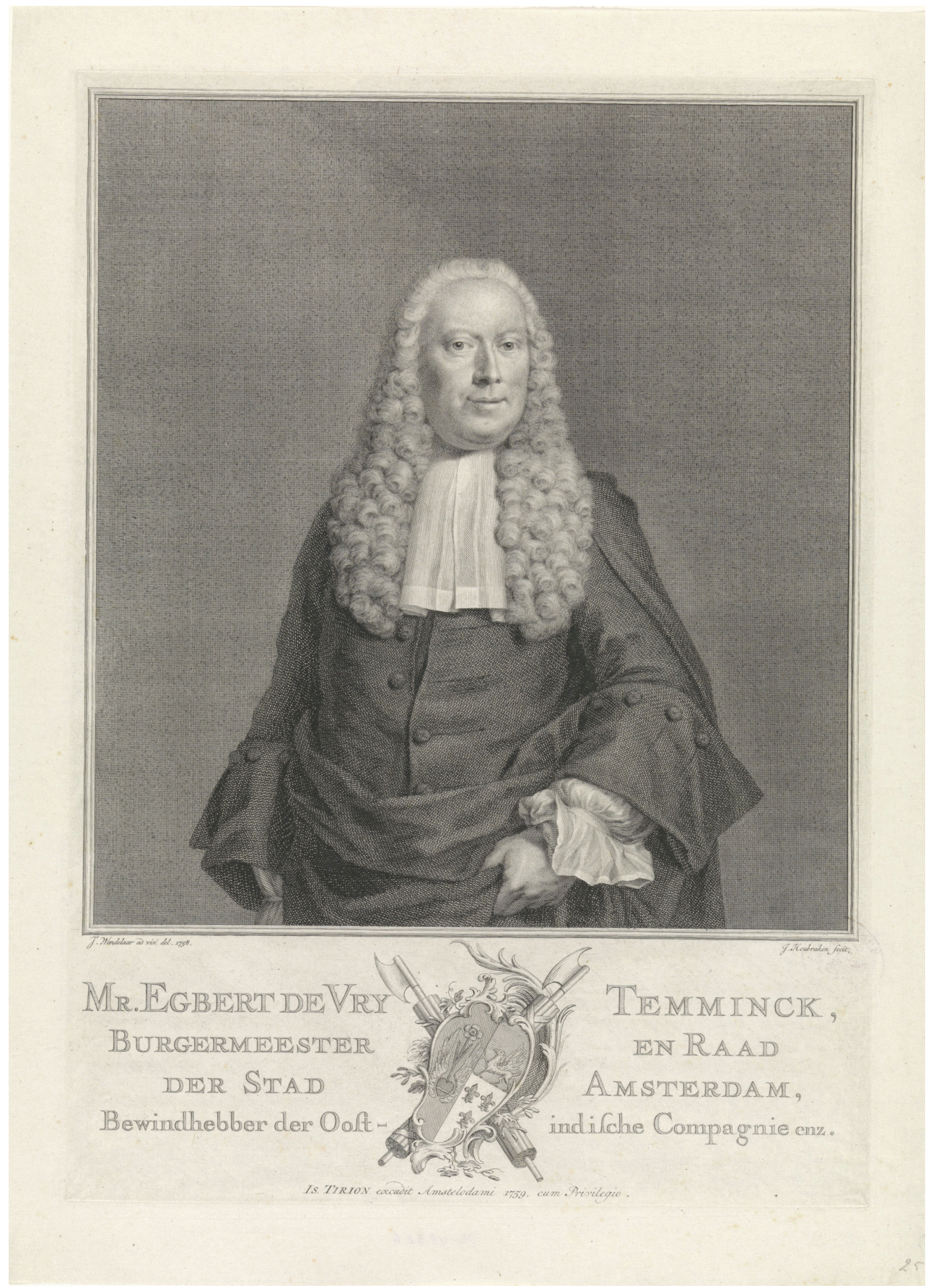

$\Delta$

Portrait of Egbert de Vrij Temminck painted by Jacob Houbraken in 1759. (C) Rijksmuseum Amsterdam, RP-P-OB-48.326, http://hdl.handle.net/10934/RMOoo1.COLLECT.126478. 
In two columns he noted, through key words, which arguments were raised by each party's counsel before the court, on which legal sources these arguments were based, and how parties replied to each other's position. Through these sources I examine under which circumstances, in the eyes of the judges, a slave could successively invoke the free soil principle. First, I will shortly set out how Snak, Claas and Bastiaan ended up in Amsterdam. There is, however, much more to say about their escape. Plenty of sources make it possible to get insight in questions like: how did enslaved people know about the free soil in the Dutch Republic, did Snak, Claas and Bastiaan get help with escaping, and is there something known about their motives? In a longer version of this article, which is accessible online, I elaborately wrote down the whole story of Snak, Claas and Bastiaan's escape. ${ }^{20}$ Then, a chronological discussion of the court cases follows. In the conclusion, I re-evaluate the statute of 1776 . The two court cases shed a different light on the legislative choice that the States General made. The statute encroached deeper on the existing legal situation than historians previously considered.

\section{Claas, Snak and Bastiaan's escape to Amsterdam}

The story of Snak, Claas and Bastiaan began in 1733, two years before their joint escape. ${ }^{21}$ In that year Nicolaas Pot travelled together with his slave Snak from Curaçao to the Dutch Republic. Pot took Snak with him as his servant. Both men lived together at the Leidse Dwarsstraat in Amsterdam for half a year. Then, Pot asked captain Van Lint if he would take Snak with him to Curaçao. Van Lint agreed, as did Snak. Snak agreed because he was under the impression that he was free as Pot had given him his freedom. Multiple witnesses confirmed that Pot had released Snak. Thus, unsuspectingly Snak parted from his former master. When Snak arrived at Curaçao together with Van Lint, it turned out he had been deceived. Pot had tricked him. Van Lint delivered Snak to Jacob de Petersen who in turn sold him into slavery to Jan van Schagen. Van Schagen was the advocate-fiscal (advocaat-fiscaal) of Curaçao, an important office within the colonial government. One of the sources adds that it appeared from 'the letters' in Willemstad that Snak had to be sold to a new master. Snak's suffering must have been immense: after briefly thinking he was free he was enslaved again.

In 1735 Snak decided to return to the Dutch Republic. Was it because of his brief experience with freedom, or the bad treatment he received? It remains unclear. This time, however, Snak parted without his master's consent.

of the Radboud University Nijmegen: Cees

Kwanten, Herman Noordkerk (1702-1771): Een onderzoeksverslag (Doctoral thesis, University of Amsterdam 1985) 153-210.

The longer version of this article is available in open access on my personal page on 
Moreover, he travelled with two other enslaved men, Claas and Bastiaan Assaij. Claas and Bastiaan were house slaves of Paulina Heijer. Heijer was the widow of Jan Ellis, owned the plantations Savonet, Zorgvliet, Knip and Paradera, and lived in Willemstad. Her house was situated in the Breedestraat, facing Fort Amsterdam and close to the harbour. Moreover, it stood next to the house of the advocate-fiscal of Curaçao, which turned Heijer and Van Schagen into neighbours. This explains how Claas and Bastiaan met Snak. It is imaginable that Snak shared his experience about the free soil principle in the Dutch Republic with Claas and Bastiaan, and that subsequently the three came up with a plan to escape. On 3 May 1735 the three men hid on board a ship of an acquaintance: the ship of Van Lint, the Maria Jacoba. Van Lint's ship was located off the coast of Willemstad and departed the same day.

While Snak, Claas and Bastiaan were at sea, Heijer and Van Schagen took action to get the three back. They authorised Maarten Hempel to capture the fugitives. Hempel was captain of the ship the Victoria that sailed from Willemstad on 29 June 1735 and arrived in Amsterdam approximately at the end of September. At that moment Snak, Claas and Bastiaan had already been in Amsterdam for roughly one month. According to court records Hempel knew that Snak, Claas and Bastiaan were within the city. He petitioned the Aldermen's Court to take the three into custody. On 18 October 1735 this provisional arrangement was granted. Awaiting their proceedings, Snak and Claas were imprisoned. Bastiaan was the luckiest: Amsterdam authorities could not find him.

\section{Snak before the Aldermen's Court}

The views of Roman-Dutch jurists such as the mentioned Grotius and Groenewegen van der Made who wrote that slavery was out of use were to the advantage of Snak and Claas. ${ }^{22}$ In the Dutch Republic everyone was free. Amsterdam customary law, in an important edition by the seventeenthcentury town secretary Gerard Rooseboom, had a separate provision in which the free soil principle was explicitly laid down. Chapter 39, which had been copied from Antwerp customary law ${ }^{23}$, states the following:

CAP. XXXIX

1. Within the City of Amsterdam and her liberty, all people are free, and none slaves. to many of these other Roman-Dutch jurists. Moreover, he cites the customs of different towns in Holland: Dionysius Godefridus van der Keessel, Praelectiones iuris hodierni ad Hugonis Grotii introductionem ad iurisprudentiam Hollandicam
(1800), ed. Paul van Warmelo, Lucas Ignatius Coertze and Henri Louis Gonin (Amsterdam 1961) Th. 45 and 46 ad 1.4.2.

23 Rechten ende costumen van Antwerpen (Antwerp 1582) Chapter 36 
2. Item, all slaves, that come into or are brought within this City and her liberty, are free and beyond the control and authority of their Masters, and Mistresses, and in so far as their Masters and Mistresses want to keep them as slaves, and let [them] serve against their will, the same persons have power to summon their aforementioned Masters and Mistresses before the Court of this City, and let them be judicially declared free. ${ }^{24}$

At first glance, the provision appears to be clear about the legal status of Snak and Claas. Not only does it confirm that slavery was out of use in Amsterdam, but pursuant to the second paragraph it also gave enslaved people the possibility to summon their masters before the court of the city to have their freedom judicially confirmed. A close reading of the text, however, reveals some ambiguities. Only slaves that 'come into or are brought within' Amsterdam are able to summon their masters before court. The precise meaning of these words is a matter of legal interpretation. 'Come' implies that it does not matter how a slave entered Amsterdam, while 'are brought' means that a slave has to be transported to the city by someone else. The legal question, then, concerns the precise relation between 'come' and 'are brought'. After all, 'are brought' is included in the meaning of 'come'. If we suppose that 'are brought' has an independent meaning, then the question arises by whom the slave has to be brought to Amsterdam. It seems obvious that the master of a slave suffices and that someone like captain Van Lint does not. But on this point the text is silent. The provision, in short, raises multiple questions. It was not clear in advance that, by relying on Amsterdam customary law, Snak and Claas had to be released.

The Aldermen's Court had various options. Depending on their interpretation of Amsterdam customary law Snak and Claas could be free. If the judges were to decide that Amsterdam customary law was not applicable, early modern legal theory was determined to fall back on Roman law. This was the basic principle across continental Europe. If local custom did not provide a solution, judges resorted to the Corpus Iuris Civilis, the famous sixth-century codification of Roman law. Therefore, it was relevant to Snak and Claas what Roman law had to say about the legal status of runaway slaves. The Codex of Justinian states:

vry ende buyten de macht ende autoriteyt van here Meesters, ende Vrouwen, ende by soo verre hare Meesters ende Vrouwen de selve als slaven wilden houden, en tegens haren danck doen dienen, vermoghen deselve persoonen hare voorsz. Meesters ende Vrouwen voor den Gerechte deser Stede te doen daghen, ende hen aldaer rechtelijck vry te doen verklaren'. 


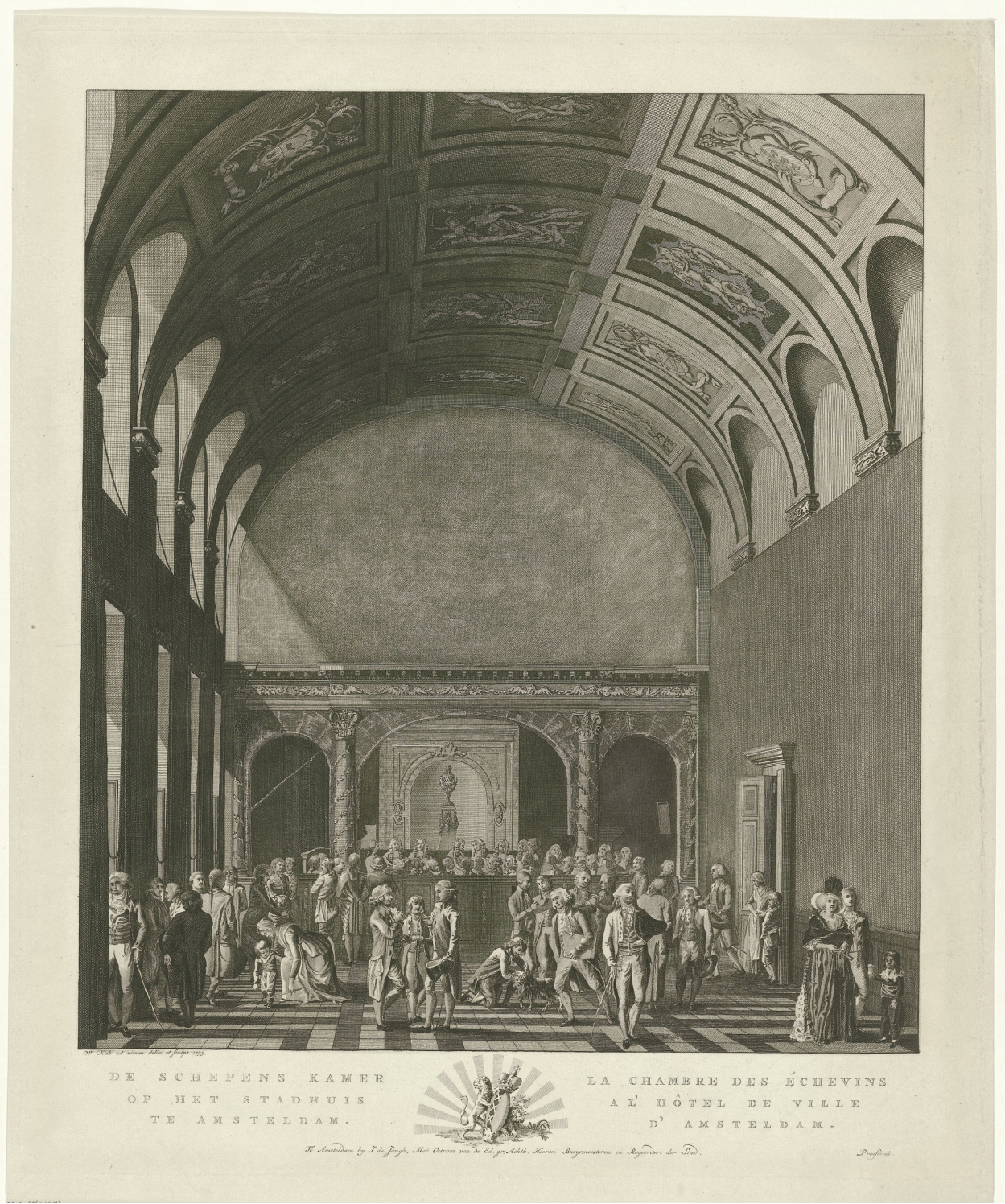

\section{$\Delta$}

In the schepenzaal, the aldermen administered justice. Willem Kok, Gezicht op het interieur van de Schepenzaal van het Stadhuis op de Dam, 1793. (C Rijksmuseum Amsterdam, RP-P-1906-3943, http://hdl.handle.net/10934/RMooo1. COLLECT.133193. 
It is clear that a fugitive slave commits theft of himself, and therefore that he is not entitled to either short-term acquisitive prescription (usucapio) nor longterm acquisitive prescription (praescriptio longi temporis), so that the escape of slaves shall not, for any reason whatsoever, result in loss to their masters. ${ }^{25}$

The reasoning of Roman law is as follows. ${ }^{26}$ When a slave runs away from their master, de iure they commit theft of themselves. Theft is not a valid acquisition of ownership. As a result, a slave can never acquire their freedom immediately after running away. However, acquisitive prescription (verkrijgende verjaring) may provide an escape route. Acquisitive prescription entails that a bona fide possessor acquires ownership after a specified time period. For a runaway slave, this could be relevant. As is shown, however, in the quote from the Codex of Justinian, Roman law blocked this escape route. Both forms of acquisitive prescription, usucapio and praescriptio longi temporis, require the possessor to be in good faith. ${ }^{27}$ A runaway slave, being legally framed as a thief, could never fulfil this requirement. Roman law, thereby, leaves no doubt as to the legal status of runaway slaves: under no circumstance can they acquire their freedom. ${ }^{28}$ Hence, Amsterdam customary law and Roman law are diametrically opposed to each other: the former is favourable to Claas and Snak, the latter to Heijer and Van Schagen.

Snak's case was heard first. In early November 1735 he had to appear before the Aldermen's Court. De Vrij Temminck's notes show that the parties indeed relied either on Roman law or on customary law. ${ }^{29}$ Jan or Johannes Creyghton was Van Schagen's lawyer. ${ }^{30} \mathrm{He}$ argued that Snak was still 'the serf' of

The usucapio will also fail, because stolen goods are not eligible for this way of acquisitive prescription. Besides, I have studied several editions of Amsterdam customary law and found nowhere that there are specific rules of acquisitive prescription in Amsterdam for enslaved people.

28 In Roman law there was one rare exception, namely for the case in which a slave ran away because the master had abused the slave severely: Digesta (Dig.) 1.6.2. In this case this is not a significant issue, because multiple witnesses testified that Snak and Claas had been treated kindly by their masters.

29 NL-HanA, Slingelandt de Vrij Temminck, 3.20.52, inv. nr. 423,103 r.

30 Because there are two Creyghtons in a list of eighteenth-century Amsterdam lawyers, it is unclear whether it is Jan or Johannes: Petrus Schouten, Naamwyzer, waar in vertoond worden de naamen en woonplaatsen van haar Ed. Gr. Acht. de Heeren Regeerders der stadt Amstelredam, dezes Jaars 1763. Als mede van eenige bedienden der zelve (Amsterdam 1763) 50. 
Van Schagen, because he had 'stolen himself thievishly'. ${ }^{31}$ Creyghton discussed multiple texts of the Corpus Iuris Civilis to strengthen his position. ${ }^{32} \mathrm{He}$ also quoted a statute enacted by the States General that had decreed that Roman law was to be applied to slaves in Dutch Brazil. ${ }^{33}$ Snak was represented by Kees Kersse. ${ }^{34}$ Kersse argued that Snak was free. When Snak and Pot had travelled to the Dutch Republic and had 'lived there for as much as half a year', Snak had acquired his freedom. ${ }^{35}$ Thereafter, Snak was 'sinisterly, if not violently, transported to Curaçao once more?. ${ }^{36}$ Additionally, Kersse appealed to two prominent Roman-Dutch jurists, Grotius and Simon van Leeuwen who both had declared that every enslaved person could rely on the free soil principle. The debate was not limited to legal arguments alone. Creyghton raised an important practical argument: 'the colonies have to be cultivated by slaves'. ${ }^{37}$ Creyghton pointed out to the aldermen that Snak's release could have important societal ramifications as it might encourage other enslaved persons to make the crossing to the Dutch Republic as well, with immense consequences for the slave population in the colonies. This argument against Snak's release potentially carried much weight, because the aldermen, being part of the Amsterdam administrative elite, had enormous personal interests in the colonies.

Recent research on the ties between slavery and the city of Amsterdam concludes that Amsterdam regents were financially and administratively deeply involved with the Atlantic slave trade. ${ }^{38}$ A closer look into the nine aldermen in Snak's case affirms this conclusion as it shows that they all maintained strong ties with the Dutch West India Company (wIC) and the Dutch East India Company (voc). ${ }^{39}$ De Vrij Temminck and Gualterus Petrus Boudaen had both been directors (bewindhebber) of the wIC. Pieter Six, Gerrit Hooft and again De Vrij Temminck had been directors of

NL-HaNA, Slingelandt de Vrij Temminck, 3.20.52, inv. nr. 423, 103r. 'de leiveigen [...] dievachtig ontstolen'. gewoont'

36 NL-HanA, Slingelandt de Vrij Temminck, 3.20.52, inv. nr. 423, 103v: '[...] op een sinistere manier, soo niet met gewelt weder vervoert na Curaçao'.

37 NL-HanA, Slingelandt de Vrij Temminck, 3.20.52, inv. nr. 423, 103v: 'de colonien moeten door slaven gecultiveert worde'.

38 Pepijn Brandon, Guno Jones, Nancy Jouwe and Matthias van Rossum (eds.), De slavernij in Oost en West: Het Amsterdam onderzoek (Amsterdam 2020).

39 See the aldermen in 1735 in: Jan Wagenaar, Amsterdam in zyne opkomst, aanwas, geschiedenissen, voorregten, koophandel, gebouwen, kerkenstaat, schoolen, schutterye, gilden en regeeringe: Derde stuk (Amsterdam 1767) 347. 
the voc..$^{40}$ Although Willem Sautijn, Nicolaas Hasselaer, Nicolaas Geelvinck, Willem van Loon and Ferdinand van Collen had not held office as directors of one of the two trading companies, their direct family members - in most cases their fathers - had. ${ }^{41}$ Nevertheless, the aldermen's personal interests did not prevail. Not economic, but legal arguments had the upper hand. On 4 November 1735 the aldermen decided in favour of the free soil principle: Snak was released and declared free. In his journal De Vrij Temminck made a short note of the secret discussions in chambers:

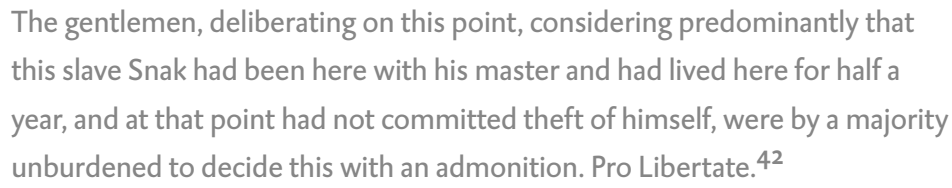

The aldermen considered that Snak had already become free once he had arrived in the Dutch Republic with his former master Pot. Being sold again into slavery was therefore unjustified.

De Vrij Temminck's notes give the impression that in the eyes of the aldermen this outcome was abundantly clear. This becomes evident from the following note: 'Sautijn wanted to air this in judicio contradictorio'. ${ }^{43}$ 'In judicio contradictorio' was a term of procedural law. It meant that the case was dealt with in its entirety, that is to say: in such a way that both parties could respond to each other's arguments through written documents and an oral hearing with pleadings. ${ }^{44}$ In Snak's case, this did not happen because his trial is best characterised as summary proceedings for preliminary relief (kort geding). Snak and Claas were seized on 18 October 1735. It was possible to raise objections to this. According to Amsterdam customary law, the person seizing another had to give a legitimate reason for the imprisonment, while the person being seized had to explain why imprisonment was unjustified. ${ }^{45}$

Amsterdam. 1578-1795, ed. William Robert Veder

(Amsterdam 1963) nr. 309 (Pieter Six), nr. 326

(Egbert de Vrij Temminck), nr. 330 (Gualterus

Petrus Boudaen), nr. 341 (Gerrit Hooft Gerritsz.).

41

3.20.52, inv. nr. 423, 103v: 'd'Heeren daerover

delibererende, geconsidereert voornamentlijk dat die slaev Snak hier met sijn meester was geweest
Elias, De vroedschap van Amsterdam, nr. 269

(Willem Sautijn), nr. 302 (Nicolaes Cornelis

Hasselaer), nr. 315 (Willem van Loon Jansz.), nr.

343 (Nicolaes Geelvinck), nr. 370 (Ferdinand van

Collen Ferdinandsz.).

NL-HanA, Slingelandt de Vrij Temminck, en een halv jaer gewoont, en sig als toen niet ontstolen had, waeren te meerder onbeswaert dit op een vermaning te decideren. Pro Libertate'. NL-HaNA, Slingelandt de Vrij Temminck, 3.20.52, inv. nr. 423, 103v: 'Sautijn wilde dit geventileert hebbe in judicio contradictorio'.

44 Wagenaar, Amsterdam in zyne opkomst, 33.

45 Hermanus Noordkerk, Handvesten; ofte privilegien ende octroyen; mitsgaders willekeuren, costuimen, ordonnantien en handelingen der stad Amstelredam. Tweede stuk (Amsterdam 1748) 495-502, 614-615, 615. In Roosenboom's version of Amsterdam customary law there is a similar regulation: Rooseboom, Recueil van verscheyde Keuren, CAP. XIX. 
During these proceedings, the aldermen had already become convinced of the strength of Snak's claim to freedom. There was no need for a comprehensive (oral) treatment in longer proceedings, and so the aldermen passed judgement 'with an admonition'. It had never been permissible to imprison Snak and therefore he had to be released immediately. Only Sautijn dissented. Maybe his personal interests played a greater part in his judgement, as his family was closely associated with the Society of Suriname. ${ }^{46}$ In 1733 Sautijn established three plantations in Suriname himself and his father, Nicolaas Sautijn, had been director of the Society between $1722-1730 .{ }^{47}$ The family's interest in slave trade was enormous.

The decision in Snak's case appears to have been a formality. There was little doubt about his freedom, and revealingly no appeal was raised against the Aldermen's Court's decision. As Van Schagen's representative, Hempel acquiesced in the decision. The chances of success were just not high enough to make an appeal worthwhile. It demonstrates that parties also recognised that the right decision had been reached. From 4 November 1735 onwards, Snak was permanently free. Hence, the free soil principle stood open to all enslaved persons who travelled to the Dutch Republic with their master's permission.

\section{Claas before the Aldermen's Court}

Being enslaved, Claas was not empowered to litigate on his own behalf, so a legal representative had to be assigned to him. On 25 November 1735 the Aldermen's Court appointed the famous Amsterdam lawyer Hermanus Noordkerk. ${ }^{48}$ A few days later, on 29 November, the counsels delivered their statements of claim and defence. The same individuals as in Snak's case acted as counsel: Kersse represented Claas and Creyghton represented Heijer. ${ }^{49}$ The case of Claas differed from that of Snak in one significant aspect: Claas had never received his master's permission to travel to the Dutch Republic. According to De Vrij Temminck's notes, this complicated things considerably. The proceedings of Claas were 'in judicio contradictorio'. Contrary to Snak's case, there was an extensive oral hearing. During this hearing, De Vrij Temminck made notes on four big folios. He made one column for each lawyer, in which he wrote down their arguments.

Oral submissions took place on 15 December 1735. Noordkerk appeared on behalf of Claas, Hugo van Son on behalf of Heijer. Van Son made the opening statement. His plea was built on two arguments which had already featured in Snak's case. 'By fleeing no slave becomes free', he argued, 1795): Het bestuur van de kolonie in de achttiende eeuw (Zutphen 2019) 122.
Stadsarchief Amsterdam (NL-SA), Schout en Schepenen, 5061, inv. nr. 1640. NL-SA, Schout en Schepenen, 5061, inv. nr. 1640. 
because Roman law was applicable. ${ }^{50}$ Once more, multiple texts from the Corpus Iuris Civilis were discussed. Secondly, Van Son argued that releasing Claas would have 'great consequence and disadvantage for the colonies'. ${ }^{1}$ Noordkerk in turn appealed to the jurists that showed that 'without distinction all persons coming to the Netherlands, are free'.$^{52}$ Grotius, Groenewegen van der Made, Simon van Leeuwen, Paulus Christinaeus, Fransicus Zypaeus, Arnold Vinnius and Paulus Voet were all cited. According to Noordkerk 'Roman law [has been] abrogated' and as a consequence there were no reasons whatsoever 'why this slave should not profit from the liberty of this country'.53

A few weeks after the oral hearing, on 31 January 1736, the aldermen gave their judgement. Again, the economic and familial interests of the Amsterdam aldermen were not decisive in resolving the case. The aldermen decided that the free soil principle also applied to slaves who had fled from the Dutch colonies to Amsterdam. Claas proved to be right and he was released as well. De Vrij Temminck noted:

Would be of mind that the claimant should have his claim refused, which has happened. ${ }^{54}$

According to this note, however, De Vrij Temminck apparently had some doubts about this outcome ('would be of mind'). Previously with Snak, this had not been the case. It emphasises that the case of Claas was substantially different and that the outcome was not as evident as it had been with Snak. Both parties also understood this because this time Hempel did appeal against the decision of the Aldermen's Court.

Claas remained in custody during appellate proceedings. On 8 February he therefore requested that the Court of Holland (Hof van Holland) would deal with his case urgently. ${ }^{55}$ This request was granted. According to court records, both parties appeared before the examining judges Gerrit Fagel and Adriaan van der Mieden on 21 February. ${ }^{56}$ Sources providing an insight into the parties' submissions before the court are unavailable. Only the statements of claim and defence are available in inv. nr. 423, [1v]: 'door de vlugt word geen slaev vrij'. inv. nr. 423, [1v]: 'groote consequentie en nadeel voor de colonien'. sijn vrij'.
53 NL-HanA, Slingelandt de Vrij Temminck, 3.20.52, inv. nr. 423, [2r]: 'het Roomsche Regt [...] g'abrogeert [...] waerom dese slaev niet souw profiteren van de vrijheyt van het land'.

54 NL-HanA, Slingelandt de Vrij Temminck, 3.20.52, inv. nr. 423, [2v]: 'Souw van gedagten sijn dat den eijscher sijnen eijsch behoorden te werden ontsegt, hetgeen geschiet is'. 


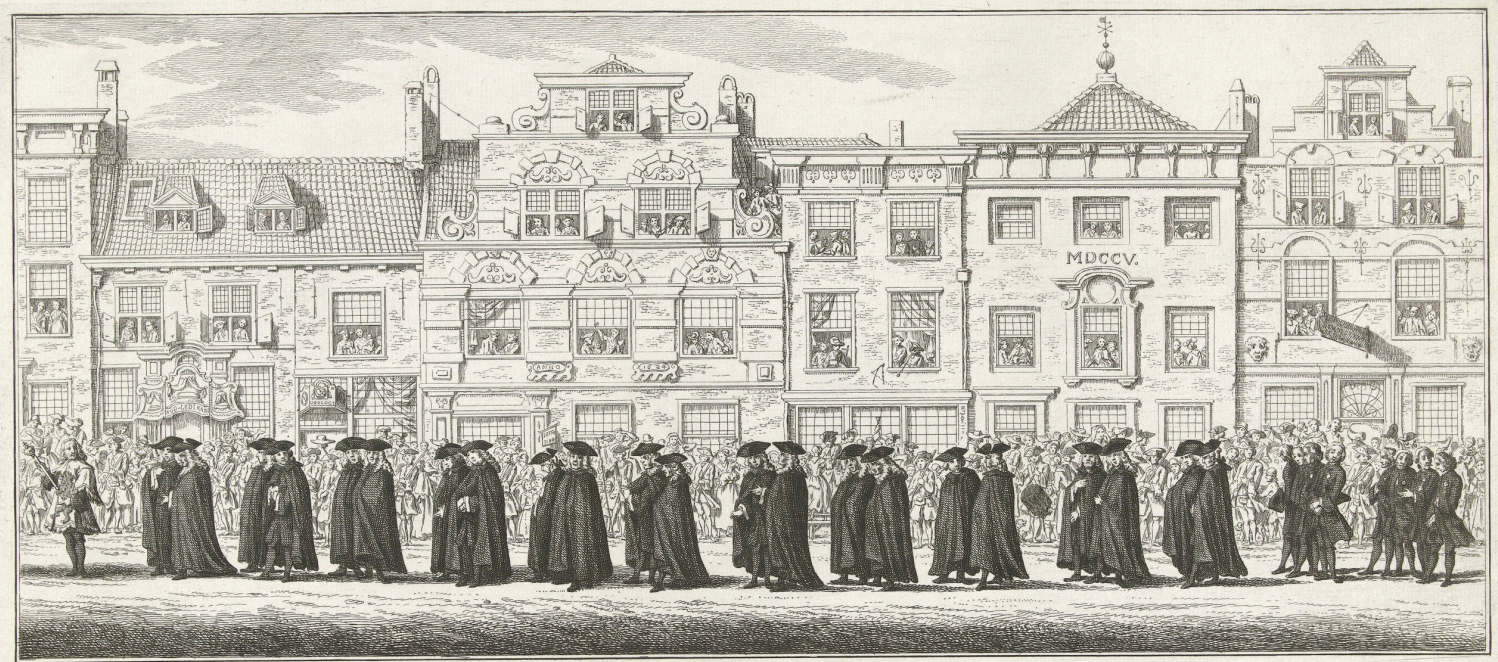

A

Members of the Court of Holland walk in Delft as part of the funeral procession of Anna of Hannover. Simon Fokke, Leden en personeel van de Hoge Raad en Hof van Holland in de lijkstoet van Anna van Hannover te Delft, 1759-1761. (C) Rijksmuseum Amsterdam, RP-P-1927-265-XIII, http://hdl.handle.net/10934/RMOoo1.COLLECT.111164. 
the archives, but these provide no new information. ${ }^{57}$ Both parties briefly repeated their arguments.

On 23 March 1736 the Court of Holland gave its judgement. The outcome was disadvantageous to Claas. The Court overturned the Aldermen's Court's judgement and awarded Heijer's claim to retrieve Claas. ${ }^{58}$ The Court's reasons for this conclusion are unknown. The published decision does not provide any information since law courts in the early modern period commonly did not motivate their judgements. ${ }^{59}$ Judges did not publicly explain the arguments on which their judgement rested. As a consequence, the published decisions of the Aldermen's Court and Court of Holland solely mention the names of both litigants and the final outcome of the case, and never the grounds for the decision. One day after the decision of the Court of Holland, on 24 March, Claas appealed to the High Court of Holland, Zeeland and West-Friesland. ${ }^{60}$ Although the published decisions of the High Court do not give insight in the grounds of the decision as well, its archives do provide more information. The archives of the High Court make it possible to discover in detail which arguments the judges discussed amongst themselves during their secret deliberations in chambers. In Claas's case, the judges had a clear view on how the free soil principle was to be interpreted.

\section{Claas before the High Court of Holland, Zeeland and West-Friesland}

At the High Court of Holland and Zeeland, Claas's case was dealt with urgently. Already on 11 April both parties appeared before two examining judges and on 20 June their advocates pleaded their cases. ${ }^{61}$ On 3 July the judges of the High Court sat in chambers to form their judgement. ${ }^{62}$ This discussion in chambers was strictly confidential and took place behind closed doors. Under no circumstances was it allowed to be made public. According to article 12 of the Instruction of the High Court a judge who broke this secrecy, was suspended after the first incident and removed from his position after the second. ${ }^{63}$ Nevertheless, three sources, which were confidential at

Europe: Willem Zwalve and Corjo Jansen,

Publiciteit van Jurisprudentie (Deventer 2013) 146-147.

Moreover, I consulted these inventory numbers in vain: NL-HaNA, Hof van Holland, 3.03.01.01, inv. nr. 963, inv. nr. 1237 and inv. nr. 5767.

NL-HanA, Hoge Raad Holland en Zeeland, 3.03.02,
61 NL-HaNA, Hoge Raad Holland en Zeeland, 3.03.02, inv. nr. 321 , scan 33 and 48 .

62 NL-HanA, Hoge Raad Holland en Zeeland, 3.03.02, inv. nr. 672, scan 2.

63 Statute States of Holland 31 May 1582, 'Ordonnantie ende Instructie van den Hoogen Raadt van appel in Hollandt', Groot-plakkaatboek v (1725) 867. inv. nr. 139, scan 752 . 
the time, allow to reconstruct the discussions in chambers. First, there are the resolution books (resolutieboeken) in which the registrar (griffier) entered minutes of what a judge had said in chambers. ${ }^{64}$ Second and third, the legal diaries (Observationes Tumultuariae) of two judges of the High Court Johan van Bleiswijk and president Cornelis van Bynkershoek have survived. ${ }^{65}$ In these two private documents they wrote down, in Latin and sometimes in vernacular, the facts and the course of proceedings as well as the grounds on which the High Court had based its decision.

It was common practice for one judge to act as reporter. In this case, it was Adriaan de Grande. He had to inform the other judges about the facts of the case and the relevant legal sources. Thereafter, he gave judgement first. One of the first texts that the judges discussed came from the Commentariorum de Iure Novissimo of the sixteenth-century Flemish jurist Petrus Gudelinus. ${ }^{66}$ Discussing the free soil principle in the Low Countries, Gudelinus refers to a case from 1531 before the Great Council of Malines, the predecessor of the High Court as the supreme law court in Holland. An enslaved man who had been purchased in Spain by a Portuguese merchant ran away from his master. When the merchant heard that his slave was dwelling somewhere in the Low Countries, he petitioned the president of the Great Council to arrest his slave. The president refused:

\section{It was answered in 1531 that the requests of the supplicant would never be approved because of the custom of freedom of persons that has been observed here for several centuries. ${ }^{67}$}

It looks like the slave of the Portuguese merchant acquired his freedom by fleeing to the Low Countries. The rest of Gudelinus' commentary, however, shows that things are not as simple. Legally the man remained a slave, but

64 NL-HanA, Hoge Raad Holland en Zeeland, 3.03.02, inv. nr. 672, scan 2-3, further: High Court resolution books 3 July 1736 . See also: NL-HaNA, Hoge Raad Holland en Zeeland, 3.03.02, inv. nr. 624 , scan 62.

65 Both diaries are called Observationes Tumultuariae (От): Cornelis van Bynkershoek, Observationes Tumultuariae I-IV, eds. Eduard Maurits Meijers and Anne Siberdinus de Blécourt (Haarlem 1926-1962) nr. 2966, further: Bynkershoek OT 2966; Johan van Bleiswijk, Observationes Tumultuariae (ОT), NL-HanA, Collectie Bisdom, 1.10.06, inv. nr. 145. At this moment I am, together with Egbert Koops and Boudewijn Sirks, editing a source edition of Van Bleiswijk's Observationes Tumultuariae.
66 This text of Gudelinus was also discussed before the Aldermen's Court. De Vrij Temminck briefly notes that Van Son submitted that Gudelinus 'speaks of a completely different situation'. There appears no further discussion. Noordkerk, for instance, did not respond to Van Son's remark. In chambers the High Court discussed the case of Gudelinus in greater detail, which is why this text is discussed here.

67 Petrus Gudelinus, Commentariorum de lure Novissimo. Libri sex (Arnhem 1643) Book 1, Chapter 4: 'Rescriptum fuisse anno 1531 supplicantis precibus nequaquam esse annuendum propter libertatis personarum usum hic per aliquot saecula continue observatum'. 
in the Low Countries his master was not entitled to arrest him. As long as he stayed in the Low Countries, he could appeal to the custom that slavery had fallen out of use and as a consequence the master's rights were suspended. But if the slave ever were to return to Spain, he could still be arrested by his master. The underlying reason is that foreign legal concepts were only recognised as far as they existed within the own jurisdiction. A contemporary of Gudelinus, Paulus Christinaeus, confirms this interpretation:

The same master Gudelinus, previously my colleague in the same Great Council, submitted that he believes that slaves who come from Spain to this place or France, strictly speaking do not acquire their freedom. For in Spain they can still be taken back into slavery, if they are later captured there, although as long as they are here, they can be defended in the liberty that is denied to them. ${ }^{68}$

For the outcome in this case it was decisive that the slave had fled from a territory where slavery was permitted, to a territory where slavery was out of use. That is why the Portuguese merchant could not arrest his slave.

Could this precedent apply to Claas as well, who fled from Curaçao to Amsterdam? The judges unanimously decided in the negative. Bynkershoek wrote in his personal notes 'that the example of Gudelinus [...] is about a slave who came from another realm (imperium).${ }^{69}$ Claas could not rely on Gudelinus's precedent, because the facts of his case were different. He himself had fled within the same realm of the Dutch Republic, from one area to another. Bynkershoek noted that some judges would indeed have come to a different conclusion if Claas had fled from a different realm. As appears from the resolution books, Van Bleiswijk was one of them:

if this slave had fled from Spain, or somewhere else, outside the colonies under the protection of the States General, it would fall within the terms of the case of Gudelinus. $^{70}$

According to the judges, colonial territories of the Dutch Republic were part of the same realm as territory of the Dutch Republic itself. Indeed, an argument could be made in favour of this line of reasoning. The monopolies

Rerumque in Supremis Belgarum Curiis iudicatarum observatarumque. Volumen Iv (Antwerp 1661) Book 7, decisio 80, nrs. 3 and 4: 'Ipse autem

D. Gudelinus, meus alias Confrater in eodem Consilio supremo, subdit se arbitrari servos Hispaniae huc vel in Franciam venientes proprie ad libertatem non per[v]enite, quin repeti adhuc in Hispania, si postea ibi deprehendantur, in servitutem possint, licet possint defendi in libertate eis denegata quamdiu hic sunt'.

69 Bynkershoek От 2966: 'Gudelini exemplum [...] esse de servo, qui ex alio imperio advenerat'.

70 High Court resolution books 3 July 1736: 'zoo deese slaeff was ontvlught uijt Spanje, of van elders, buiten de Colonien onder de Protectie van Haar Hoogh. Mogende, zou het vallen in de termen van het geval van Gudelinus'. 


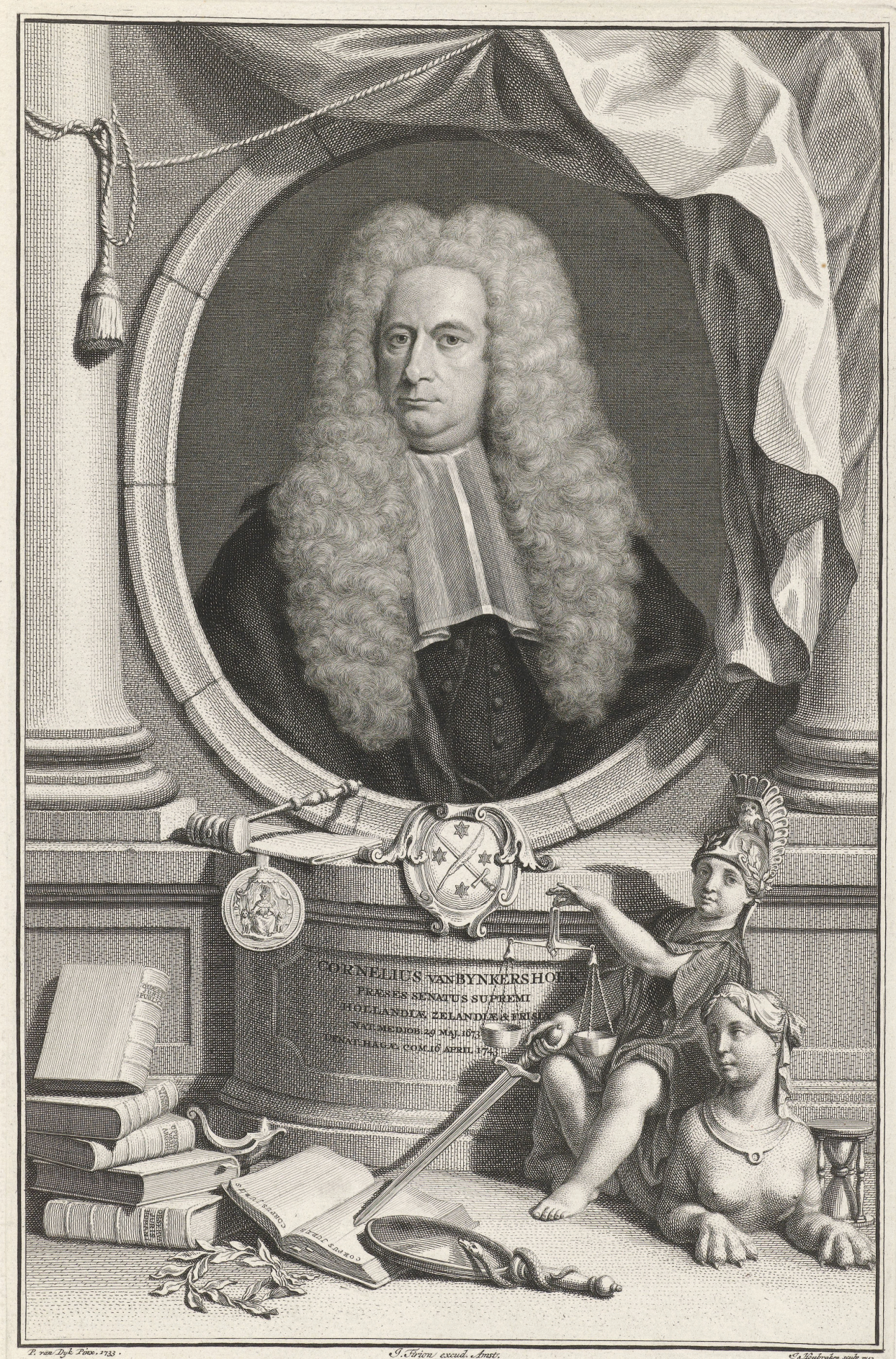

$\Delta$

Jacob Houbraken, Portret van Cornelis van Bynkershoek, 1743. () Rijksmuseum Amsterdam, RP-P-OB-48.882, http://hdl.handle.net/10934/RMO001.COLLECT.125825. 
of the WIC from 1621, from 1675, and the Instruction for colonies like Dutch Brazil and Curaçao, were all granted by the States General. The States were authorised for both territories to enact statutes. Besides, they were officially the highest appeal court of the Dutch colonies. Although this competence was delegated to the High Court, it confirms that the States General held the final power of government over the colonies. Or as Van Bleiswijk put it: the Dutch Republic and its colonies both fell 'under the protection of the States General'. Claas had not fled from another realm into that of the States General, and therefore Gudelinus's case did not offer him a solution.

Now Amsterdam customary law was Claas's last resort. Reporter De Grande found, however, that the custom of Amsterdam 'supposes that this slave is here with his master. ${ }^{, 71}$ The other judges concurred, again unanimously. Bynkershoek noted that a successful reliance on the free soil principle is only possible for slaves 'who come here with the consent of the master. ${ }^{72}$ Van Bleiswijk wrote the same. Although 'it is not found in the published work under the title Handvesten [...] der stad Amsterdam', the custom of Amsterdam 'applies to slaves who come here with their master, not to slaves who come here fleeing. ${ }^{73}$ So, according to the judges of the High Court, Rooseboom's edition of Amsterdam customary law had to be interpreted restrictively. 'Come' was interpreted to have no independent meaning since 'are brought' implied that an enslaved person needed permission from their master. Thus, the free soil principle stood only open to slaves who had their master's consent to travel to the Dutch Republic.

This restrictive interpretation of Amsterdam customary law can be explained. The High Court had a long tradition of interpreting customary law restrictively, i.e. by avoiding the use of analogy. This so-called Bartolist interpretation method, named after the famous fourteenth-century Bolognese law professor Bartolus de Saxoferrato, was almost consistently practiced throughout continental Europe, particularly by superior courts like the High Court. Generally, it interpreted customary law restrictively and Roman law extensively. Even so, the Bartolist interpretation method cannot fully explain the outcome in Claas's case. Even with a restrictive interpretation of Amsterdam customary law, that is to say a literal reading, it could have been argued just as convincingly that the provision on 'slaves, that come into or are brought within' Amsterdam does not imply the master's consent. An opposite conclusion could have been possible within the High Court's usual

'supponeert dat die slaaf met zijn meester hier is'. 
interpretation method. Bynkershoek gives another argument that may have been decisive in chambers:

Finally, because these and other colonies inevitably require slaves, without whom the colonial affairs cannot proceed, they thought that it would have great consequences if slaves from the East or West Indies would conceal themselves in ships, like Pamphilus [Claas] had concealed himself, and turn up here to walk around freely. ${ }^{74}$

This practical argument had already been put forward by reporter De Grande. He concluded that 'the colonies in the West Indies cannot be cultivated without slaves, therefore one must not give slaves a reason to escape'. ${ }^{95}$ Contrary to their colleagues in the Aldermen's Court, the judges of the High Court proved receptive to this practical consideration. It is reasonable to assume that it has substantially influenced them. After all, another interpretation of Amsterdam customary law was possible just as easily.

Now that Claas could not rely on the free soil principle, it was inevitable that the judges applied the rules of Roman law. This was also based on article 61 of a statute that the States General had enacted for the 'conquered and to be conquered places in the West Indies' ${ }^{76}$ It was decreed that the 'written common law' (gemeene beschreven rechten), i.e. Roman law, determined the legal status of slaves. I have already discussed that this outcome entailed no good for Claas. Van Bleiswijk summarised it in his personal notes:

Because the home-born fugitive slave has violated this place by committing theft of himself from his mistress, [he is] himself a thief and at the same time a stolen good. The Batavian air that he wishes to breathe against the laws of the Republic, does not excuse his crime. The crime deserves punishment and does not bestow an enormous benefaction on the perpetrator, (no one can

Bynkershoek anonymised parties in his personal notes, which is why he writes about Pamphilus and not about Claas. Bynkershoek От 2966:

'Tandem quia haec et aliae coloniae necessario indigent servis, sine quibus res coloniarum expediri non possunt, magnae consequentiae esse putabatur, si servi ex India Orientali et Occidentali sese in navibus occultarent, ut occultaverat Pamphilus, et hunc adverti libere ambularent'.

High Court resolution books 3 July 1736: 'de Colonien in de West Indien kunnen zonder slaeven niet gecultiveert worden, daaerom moet men dan ook geen voet aan aan de slaeven geeven om te ontvlughten'.

76 Statute States General 13 October 1629, 'Reglement voor de plaetsen verovert, ende te veroveren in West-Indien', Groot-plakkaatboek II (1664) 1246.

77 Van Bleiswijk от 139: 'Quod eo loci violavit verna fugitivus, sui ipsius furtum faciens dominae, ipse fur et simul res furtiva; aer Batavus non purgat delictum ejus qui contra leges republicae eum respirare vult, delictum meretur poenam non ingens beneficium auctori tribuit, (nemo ex suo delicto meliorem suam conditionem facere 
make his condition better with his crime). Our Republic is not an asylum for thieves, neither a lurking-place for stolen goods, and the right is maintained for everyone, citizen, foreigner, stranger, to claim their property and then their good is assigned to them. ${ }^{77}$

The High Court gave their final judgement the same day as their secret deliberations in chambers. On 3 July 1736 Bynkershoek pronounced that the judges were 'not encumbered' with the decision of the Court of Holland. ${ }^{78}$ Claas had to leave Amsterdam with the first ship that sailed back to Curaçao.

\section{Conclusion: a revaluation of the States General's statute of 1776}

Van Schagen v. Snak and Claas v. Heijer show under which circumstances a slave could successfully appeal to the free soil principle in the Dutch Republic. Following Van Schagen $v$. Snak, a slave became automatically free when a master took his slave with him to the Dutch Republic. According to the Aldermen's Court, the same applied to fugitive slaves. In Claas v. Heijer it was decided that slaves who did not have their master's permission to make the crossing to the Dutch Republic, could also rely on the free soil principle. Irrespective of their personal interests in the slave trade the Amsterdam aldermen decided to release both Snak and Claas. The Court of Holland and the High Court held a different opinion. The reasons for this are only known for the High Court. The High Court confirmed that slaves with their master's permission to travel to the Dutch Republic acquired their freedom. If Van Schagen v. Snak would have reached the High Court, Snak would have won his case. But with regard to escaped slaves the free soil principle needed to be interpreted restrictively. The custom did not apply to fugitives. The phrase 'slaves, that come into or are brought within' Amsterdam from Chapter 39 of Rooseboom's version of Amsterdam customary law implied that a slave needed their master's

55 permission. As a result the judges applied the rules of Roman law. Roman law was unequivocal: under no circumstance could a fugitive slave acquire their freedom. They always remained their master's property.

Finally, the situation was different when an enslaved person had fled from territory that was not part of the realm of the States General. In that case, a decision of the Great Council of Malines from 1531, reported by Gudelinus, offered a solution. The slave who had fled from Spain to the Low Countries strictly speaking did not acquire his freedom, but as long as he stayed here

potest), res publica nostra non furium asylus, non verum furtivarum receptaculum est, cuique rem suam persequenti civi, forensi, peregrino jus dicitur et res sua tribuitur'.
78 NL-HaNA, Hoge Raad Holland en Zeeland, 3.03.02, inv. nr. 916 , scan 86 . 
he could rely on the free soil principle. Whilst not legally, factually he was free. This case did not help Claas. Curaçao and the Dutch Republic both formed part of the realm of the States General as was proved by multiple statutes that the States had enacted. The judges of the High Court, therefore, decided unanimously that Claas had to return to Heijer.

The judges interpreted the free soil principle ingeniously. It mattered from where and in what way an enslaved person had ended up in the Dutch Republic. On the basis of legal and practical arguments they had come to this classification. There is, however, something that one has to keep in mind. As we have already seen, early modern judges did not publicly motivate their judgements. As a consequence most of the argumentation that we have seen in the resolution books, De Vrij Temminck's journal and Bynkershoek and Van Bleiswijk's legal diaries, were unknown to contemporaries. This is visible in a later anonymous commentary on Grotius's Inleidinge from 1778. After initially finding 'that slavery in this country is not in use, but on the contrary all slaves [...] immediately become free' it discusses Claas v. Heijer:

\section{However we have to note that by no means this right has to be extended to slaves that have fled from their masters out of the Colonies, thereof a notable example has existed [...] of a certain fugitive slave, named Claas. ${ }^{79}$}

From Claas v. Heijer legal scholars had only deduced that a slave who fled from the Dutch colonies to the Dutch Republic could not successfully appeal to the free soil principle. The prominent Leiden professor Dionysius van der Keessel discussed Claas v. Heijer in a similar fashion. ${ }^{80}$ What the High Court thought about Gudelinus or slaves who did have their master's permission to come to the Dutch Republic remained unknown to the public.

Moreover, any reference to Van Schagen v. Snak is missing. It did not draw the attention of legal scholars. Maybe this was the case because in Van Schagen v. Snak parties only litigated in summary proceedings for preliminary relief before the Aldermen's Court. As they never appealed to the Court of Holland and the High Court, Van Schagen v. Snak could be less important. Another explanation, however, is more likely. Van Schagen v. Snak never reached the legal handbooks because its outcome was so evident that including it was simply unnecessary. Of course an enslaved person could rely

Genootschap van Rechtsgeleerden (Ab omnibus libenter disce, quod nescis), Rechtsgeleerde Observatiën, dienende tot opheldering van verscheide duistere, en tot nog toe voor het grootste gedeelte onbewezene passagien uyt de Inleidinge tot de Hollandsche Rechtsgeleerdheid van wylen mr Hugo de Groot. Deel Iv (Amsterdam 1778) 64-66: 'Dat de slaverny hier te lande niet in gebruik is, maar dat integendeel alle slaven [...] datelyk vrij worden.

Egter moeten wy remarqueren dat dit regt geenszints behoord uitgestrekt te worden tot slaaven die uit de Colonien van hunne eygenaaren zijn weggeloopen, gelyk daarvan een notabel voorbeeld heeft geëxsteerd [...] tot zekeren weggelopen slaaf, Claas genaamt'.

8o Van der Keessel, Praelectiones, Th. 46 ad 1.4.2. 
on the free soil principle in such a situation. How obvious Snak's freedom was already became clear in the treatment of his case, as the aldermen were already convinced of Snak being right during summary proceedings for preliminary relief. With the exception of Sautijn the aldermen did not desire a comprehensive treatment of the case. Moreover, Van Schagen's representative Hempel raised no appeal against the decision. So, the handbooks never included Van Schagen v. Snak because it revealed nothing that contemporaries did not already know.

The conclusion has to be that the free soil principle was developed well before the 1770 . The scope of this legal principle had already been determined in the 1730 . Van Schagen v. Snak confirmed something obvious, while in Claas v. Heijer the free soil principle was limited. This places the statute of the States General of 1776 in a new perspective. Article 2, for instance, is simply a codification of the rule in Claas $v$. Heijer. It prescribed that slaves who clandestinely fled from the colonies to the Dutch Republic did not obtain their freedom. As appears from resolutions of the assembly where the States General discussed the draft version of the statute, they knew about Claas v. Heijer. ${ }^{81}$ Lawyers had informed the States General that the Courts had determined that fugitives from the Dutch colonies were not free on Dutch soil.

But Claas v. Heijer and Van Schagen v.Snak reveal something more important. Before the statute was enacted, it was evident to contemporaries that an enslaved person could rely on the free soil principle when they had their master's consent to travel to the Dutch Republic. If the States General wanted to change this, they had to pass new legislation. Only a new statute could alter the status quo. This insight leads to the conclusion that the States General consciously encroached upon the existing rights of slaves in the Dutch Republic in order to favour the slave owners in the colonies. The insertion of the six-month term and the possibility to extend this term worsened the position of enslaved people considerably. A slave was not immediately free when they touched 'free' soil, as was still the case in Van Schagen v. Snak and the two resolutions from the introduction. Hence the statute of 1776 ended a legal situation that previously had been obvious. Now the free soil principle was also curtailed for enslaved people who did have their master's permission to make the crossing.

Within the contemporary international context this decision of the States General is striking. The French, English and Scottish cases from the introduction show that surrounding countries were going in a different direction. There the situation of slaves was not undermined but was either upheld or improved. This had happened on the basis of a legal discourse similar to that in the Dutch Republic. Everywhere the same tension existed

Missive van Gouverneur en Raaden van Suriname, concerneerende de vryheid der Slaaven die in het Vaderland zyn geweest', 4. https://books.google. 
between, on the one hand, the free soil principle and, on the other hand, the property rights of plantation owners. In Somerset v. Stewart, moreover, the legal representatives of Somerset adduced Gudelinus's case. ${ }^{82}$ Lord Mansfield's judgement even bears resemblance to the same kind of reasoning. After all, Mansfield did not legally release Somerset. He only decided that on English soil Stewart could not deport Somerset against his will. Besides, in France there was also new legislation enacted in which the free soil principle was limited. The Admiralty Court in Paris and the Parliament of Paris continued nevertheless to release enslaved people on French soil, notwithstanding the property rights of masters or the supposed consequences for the slave population in the colonies.

The Scottish case of Knight v. Wedderburn may be the best example that a different outcome on the basis of the same legal discourse would have been possible since Scotland was influenced by Roman-Dutch law. Yet, the majority of the Court of Session agreed with an earlier decision of a lower court that ruled 'that the state of slavery is not recognised by the laws of this kingdom and is inconsistent with the principles thereof and [...] that the regulations in Jamaica concerning slaves do not extend to this kingdom'. ${ }^{83}$ In conclusion, despite the similarities with neighbouring countries the States General of the Dutch Republic worsened the conditions of slaves on their own soil. In doing so, they stood alone.

Finally, how did the story of Claas end? It is not entirely clear. The High Court ordered that Claas had to return to Heijer with the first ship that sailed back to Curaçao. I have not been able to determine unequivocally if this really happened. Nevertheless, it seems obvious that it did. Heijer would have insisted that the High Court's decision was complied with. The result of the three's escape, however, is clear. For one of them the journey to Amsterdam became a disillusion, Claas returned into slavery. But for the other two a dream came true. Bastiaan escaped and Snak obtained his freedom. The powerful words of De Vrij Temminck applied to them: Pro Libertate.

Tim van Polanen works as a PhD-fellow at the Department of Legal History at Leiden University. His main research interests are Roman-Dutch law, Roman law, modern private law, Dutch (colonial) history and slavery. Currently, Van Polanen works on his PhD-project about judicial decision-making within the High Court of Holland, Zeeland and West-Friesland. E-mail: t.a.van.polanen@law.leidenuniv.nl. 